\title{
The Implementation of Parate Executie of Mortgage under Plateau Price in an Effort of Solving Bad Loan (Analysis on Verdict of Supreme Court of the Republic of Indonesia Number: $471 \mathrm{~K} / \mathrm{Pdt} / 2015$ )
}

\author{
Ikhwan Ikhsan; Busyra Azheri; Rembrandt \\ Faculty of Law, Andalas University, Padang, Indonesia
}

http://dx.doi.org/10.18415/ijmmu.v6i5.1087

\begin{abstract}
The objectives of this present research are: 1) to know and to analyze legal consideration done by judges towards limit value under plateau price from auction object in the implementation of Mortgage Parate Executie as the Effort to Solve Bad Loan; 2) to achieve legal certainty in determining limit value in the implementation of Mortgage Parate Executie in order to achieve legal justice in the community. In this research, the writers conduct judicial normative; this research is descriptive-analytical; data obtained are based on secondary data by doing library research and document study. From this research result, it is known that: 1) judges' verdict in case of the implementation of mortgage parate executie is determined by the approach used by the judges to adjudicate. In the case study researched, the judge tends to consider good attention from the auction holder. Therefore, if the technical regulation regarding to auction, the judge assumes that the auction has been done legally although the determination of limit value by the auction appellant is not reliable from scientific method side in determining it; 2) the effort that can be done in order that the implementation of mortgage parate executie can run well is by doing revision of implementation regulation from technical guidelines of auction. It is in order that State Assets and Auction Service Office can be given authorities to conduct correction towards limit value determination of mortgage object determined by the auction appellant.
\end{abstract}

Keywords: Parate Executie; Auction; Mortgage

\section{Introduction}

Being a developed country is the expectation wanted by every nation. The advancement of a country can be seen from using one of indicators such as national development in the country. National development is the sustainable development effort for the sake of realizing just and prosperous Indonesian community based on Pancasila (Five Principles) and 1945 Constitution of the Republic of Indonesia. In order that the national development can be in line with the national economy development that moves 
fast, competitive, and integrated with the challenges that become more complex and financing system that becomes more advanced, policy adjustment is needed in economy, including banking. ${ }^{1}$

In its practice, credit distribution done by bank to community is always regulated in a contract as the legal relation base. Credit contract is the manifestation that proves that the agreement between creditor and debitor is occurring. It means that the bank, as the creditor, has believed the debitor candidate by the principles of trust and carefulness have been achieved implemented by bank. The credit contract has a form that prevails generally. However, in its practice, it is usually attached with some terms that will be used in the contract, number and period of loan, and the payment, interest determination and its fine if the debitor neglects it ${ }^{2}$. According to $\mathrm{Ch}$. Gatot Wardoyo, credit contract has several functions, namely: (1) as the main contract; meaning that credit contract is something that determines whether the contract is null or not and other contracts that follow it, for example security agreement; (2) as a proof regarding limitations of rights and obligations between creditor and debitor; and (3) as a tool to conduct credit monitoring. ${ }^{3}$

In the present time, the security used by the banking is security in form of assets. Security in form of assets is security in form of absolute rights on assets that have characteristics such as having direct relation with particular asset (s) from the debitor, can be maintained by everyone, always following the assets and can be transferred. Security in form of assets can be in form of movable assets or immovable assets. Movable asset is the asset that naturally can move or can be moved or because the laws consider it as movable asset like the rights attached on the movable assets. Asset is considered as immovable asset is because the asset naturally cannot move or cannot be moved, for its nature.

The regulation of Article 20 Sub-section 1 letter a and b in Law of Mortgage becomes the reference of bank to solve debitor loan if bad loan occurs. From the option of Article 20 in this Law of Mortgage, what becomes the problem is when the bank conducts parate executie towards mortgage security because this way is the forcing effort done by bank for the sake of saving their assets.

Regarding to the definition of Parate executie in Law of Mortgage, it does not provide clear explanation so that it raises several interpretations in implementing it. Parate executie according to Subekti is running by oneself or taking by oneself what has been his rights, meaning that without judge's help, addressed on a security in form of asset to then sell his own assets. ${ }^{4}$ Besides, Tartib argues that parate executie is the execution done by the mortgage holder himself without any help or assistance of District Court, but is only based on the help of State Assets and Auction Service Office. ${ }^{5}$

Referring to the explanation above, it can be stated that bad loan solution can be done by mortgage parate executie through State Assets and Auction Service Office. In addition, the Decree of Finance Minister Number 93/PMK.06/2010 regarding the guildeline of Auctio, but its implementation cannot be free from issues. The issue that is frequently problematized by the debitor as the executed party is towards the sales of auction object under plateau price or even found that the creditor sells the object not by using liquidity value but by using loan value. ${ }^{6}$

\footnotetext{
${ }^{1}$ Hermansyah, 2006, Hukum Perbankan Nasional Indonesia,Edisi Revisi, Kencana,Jakarta,hlm 40.

${ }^{2}$ Muhamad Djumhana, 2001, Hukum Perbankan di Indonesia, Citra Aditya Bakti, Bandung,hlm 387.

${ }^{3}$ Ch.Gatot Wardoyo dalam Anton Suyatno,2018,Kepastian Hukum dalam Penyelesaian Kredit Macet,Prenadamedia,Depok,hlm 38 .

${ }^{4}$ Subekti, The Implementation of Bounding, Real Execution, and Dwangsom, In; Legal Finding and Legal Case Resoultion, Development Project of Justicial Technique, MARI, Jakarta, 1990, p 69 cited from Herowati Poesoko, Op.Cit p 4

5 Tartib, Januari 1996, Record about Parate Executie, Article in Varia Peradilan Magazine Th.XI, No.124, hlm 149-150 cited from Herowati Poesoko, Ibid

${ }^{6}$ https://www.djkn.kemenkeu.go.id/artikel/baca/5097/Perbuatan-Melawan-Hukum-dalam-Gugatan-Pelaksanaan-Lelang-diKPKNL.html accessed in February 26, 2019, at 13.25 Western Indonesian Time
} 
The problems explained aforementioned are those who are frequently complained by the debitor because the justice value is not there in the sales of auction object. Whereas one of the principles in the auction is justice meaning that in the process of auction, it shall be able to meet justice principle proportionally for every involved party. This principle is to prevent the occurrence of bias done by auction officer to particular auction participant or having tendencious side to seller interst only. The case regarding injustice in doing auction of mortgage can be seen in verdict Number 274/Pdt.G/2013/PN.Bdg in District Court of Bandung.

In that case, the judge adjudicates mainly stating that the auction conducted in State Assets and Auction Service Office of Bandung is illegal and not having legal power. The judge consideration in stating that the auction is illegal is because the evidence shown by the auction appellant (The Accused I) does not have appraising result evidence from the appraiser or from the appraising team done by Bank in casu of the Accused I based on the method that can be reliable so that the determination of limit value is doubtful for its accuracy. ${ }^{7}$

After the Panel of Judges in District Court of Bandung hands down a verdict, the Accused does not accept the verdict from the panel of judges in the first-level court and the Accused files an appeal to the Provincal Court. The attempt of the accused in filing an appeal results to good outcome where his appeal number 319/PDT/2014/PT BDG is realized from the Accused by the Panel of Judges in the Provincial Court of Bandung.

The verdict of the District Court of Bandung Number 274/Pdt.G/2013/PN.Bdg jo verdict of the District Court of Bandung Number 319/PDT/2014/PT BDG, also there is an appeal verdict by the Judge of Supreme Court Number 471K/PDT2015 which mainly strengthen the previous verdict of Provincial Court.

\section{Research Method}

The method used in this research is judicial normative which means that a scientific research procedure that refers to legal norms existed in the laws and court verdicts as well as prevailing legal norms in the community. ${ }^{8}$ In this type of legal research, sometimes law is concepted as what is written in law (law in books) or law is concepted as a norm which is the standard of human behavior considering proper. $^{9}$

The choice of this judicial normative research approach focuses on secondary data source. By utilizing secondary data source, the writers make analysis by using law materials so that the writers are able to make a conclusion to answer the problems that the writers make in this thesis' research problem.

Besides, this research is descriptive analytical that exposes prevailing regulations regarding with law theories that becomes the object of research. It is also law in its implementation in the community regarding to the object of research. ${ }^{10}$

The research that the writers make is normative legal research referring to secondary data. Secondary data is the data obtained through library research ${ }^{11}$ conducted in the library of Andalas

\footnotetext{
${ }^{7}$ See Verdict Number 274/Pdt.G/2013/PN.Bdg, is handed down in February 18, 2014, p. 28

${ }^{8}$ Zainuddin Ali, 2009, Methodology of Legal Research, Sinar Grafika, Jakarta, p. 105.

${ }^{9}$ Amiruddin dan Zainal Asikin, Op.Cit, p 118

${ }^{10}$ Zainuddin Ali, Op.Cit, p. 107.

${ }^{11}$ Suratman dan Philips Dillah, 2012, Method of Legal Research, CV Alfabeta, Bandung, p. 115
} 
University, library of Law of Faculty of Andalas University, and personal library. Furthermore, the obtained data are summarized to be law materials that cover:

1. Primary material is the material or data obtained through library research which is boundover material.

2. Secondary law material is the material obtained by studying scholars' opinions, research results, books and magazines regarding to this main problem. ${ }^{12}$

3. Tertiary law material is the law material that provides guideline and explanation towards primary and secondary law materials. In this research, tertiary law material can be obtained from dictionaries used to the explanation of this research.

All contributive data in this research is obtained by way of documentary study (documentary study) meaning that the data are collected by studying documentary materials or written data especially those which are related to the problems that will be discussed. All obtained data will be processed by using editing. Not all obtained materials will be taken and be inserted. The selected materials are only law materials that have relation with the problems so that a more structured law material can be obtained. ${ }^{13}$.

After the related materials are selected, the writers then correct, check, and analyze the obtained data again so that it becomes a collection of data that truly can be made as an accurate reference in the conclusion making. The law materials that have been obtained from documentary study will be processed and analyzed qualitatively which means that the data analysis is done by analyzing, interpreting, and making conclusion as in accordance with the discussed problem, and putting it in form of sentences. ${ }^{14}$

\section{Result and Discussion}

Case Description of Mortgage Parate Executie Implementation under Plateau Price in Case Number 471 K/Pdt/2015 jo 319/PDT/2014/PT.BDG jo 274/Pdt.G/2013/PN.Bdg

The case number $471 \mathrm{~K} / \mathrm{Pdt} / 2015$ jo 319/PDT/2014/PT.BDG jo 274/Pdt.G/2013/PN.Bdg is the suit case toards auction done by State Assets and Auction Service Office based on the auction proposal conducted by PT.Bank Mega, Tbk. This case is filed by the Accused to the District Court of Bandung on behalf of H.Arifin Marahayu (the Plaintiff I) and M.Tio Agung Santika (the Plaintiff II) against PT.Bank Mega, Tbk (the Accused I), Arief Hidayat (the Accused II), the Government of the Republic of Indonesia Cq. Finance Minister of the Republic of Indonesia Cq. General Directorate of State Assets Cq. State Assets and Auction Service Regional Office of West Java Cq. The Head of State Assets and Auction Service Office of Bandung (the Accused III), and the Government of the Republic of Indonesia Cq. National Land Agency of the Republic of Indonesia Cq. National Land Agency Regional Office of West Java Province Cq. Head of National Land Agency Office of Bandung (the Accused IV). ${ }^{15}$

In that case, in November 18, 2011, the Plaintiff II made Credit Contract with Financing Facility provided by Mega Small and Medium Enterprises (Mega UKM) number 2312/PK-SME/WIL/BDG/11. Based on the credit contract, PT. Bank Mega. Tbk distributed credit fund of IDR 500.000.000 (five

\footnotetext{
${ }^{12}$ I Made Pasek Diantha, 2017, Methodology of Normative Legal Research, Prenada Media Grup, Jakarta, p. 125

${ }^{13}$ Ibid

${ }^{14}$ Mardalis, 2010, Approach Method: A Proposal Approach, Jakarta, Bumi Aksara, p. 83

${ }^{15}$ See the Verdict of District Court of Bandung Number 274/Pdt.G/2013/PN.BDG, p. 1-2
} 
hundreds million rupiah) with security in form of Mortgage. In addition, the mortgage object was in form of the land owned by the Plaintiff I for the loan security of the Plaintiff II.

In the deed of Mortgage Number 1178/2012, it was explained that the mortgage was granted for loan payment security until IDR 625.000 .000 (six hundreds twenty five millions rupiah) in which the value was $70 \%$ from the appraising value of the Accused I towards Mortgage Object owned by the Plaintiff I. It showed the appraising value of the Accused I was IDR 812.500.000,-(eight hundreds twelve millions and five hundred thousands rupiah) so that the real market value on land and building that becomes the mortgage object owned by the Plaintiff I at that time was above IDR 812.500.000,- (eight hundreds twelve millions and five hundred thousands rupiah). ${ }^{16}$

Referring to the credit contract between the Plaintiff II and the Accused I that the loan of the Plaintiff II that must be paid to the Accused I has been determined by the Accused I is of IDR 483.000.000,-(four hundreds eighty three millions rupiah) as in the letter of the Accused I to the Plaintiff II Number 282/Remedial/RBDG/ III/13 dated March 4, 2013, in which it confimed that auction would be done with limit value of loan object is IDR.483.000.000,-,-( 000,-(four hundreds eighty three millions rupiah) in which the limit value is in line with the total of payment of the Plaintiff II to the Accused I.I. ${ }^{17}$

That the auction done by the Accused III towards land and building owned by the Plaintiff is one based on the request of the Accused I based on the Decree of Finance Minister Number 93/PMK.06/2010 regarding Guideline of Auction, the determination of limit value shall be done based on the professional's assessment in which the Accused I has determined the limit value of IDR 483.000.000,- in which the total of limit value is under Sales Value of Taxable Object 2013 which is of IDR 755.297.000,- ,-(seven thousands fifty five millions two hundreds ninety seven thousands rupiah) so that it leads to loss of 272.297.000,- (two hundreds seventy two millions two hundreds ninety seven thousands rupiah) on the Plaintiff and it shows that the Accused I has not been professional and has violated laws based on the regulation of Article 1340 of Civil Code because the sales shall not harm the third party.

By this Sales Value of Taxable Object, the Plaintiff apparaises proper price on the mortgage object minimum as line with this Sales Value of Taxable Object price so that which this legal reason, the plaintiff can file a lawsuit to the District Court of Bandung. After the Panel of Judges announce the verdict Number 274/Pdt.G/2013/PN.Bdg, the Accused in February 27 filed an appeal with number of appeal document is WII.UI/2952/HT.02.02/VIII/2014. ${ }^{18}$ After the Panel of Judges in Appeal Level checked the case documents, then in August 20, 2014, the Judges announced the case verdict number 319/PDT/2014/PT.BDG with the main verdict that accepting the appeal from the Accused and annulled the verdict of District Court Number 274/Pdt.G/2013/PN.Bdg in February 18, 2014.

Regarding with the verdict of Appeal Court that annulled the verdict of Disctrict Court, the Appealed that is previously the Plaintiff filed an appeal to the Supreme Court of the Republic of Indonesia. This appeal was filed by the appeal appellant (the Appealed/the Plaintiff) in November 4, 2014 in which the Number of Appeal Document Letter was W11.U1/0220/HT.02.02/2015. ${ }^{19}$ After the Panel of Judges of the Supreme Court inspected the appeal, the panel rejected the appeal which was stipulated in the case verdict number $471 \mathrm{~K} / \mathrm{Pdt} / 2015$ stating that the appeal was rejected.

\footnotetext{
${ }^{16}$ Verdict of District Court of Bandung Number 274/Pdt.G/2013/PN.Bdg, , in February 18, 2014, p. 2-3

${ }^{17}$ Verdict of District Court of Bandung Number 274/Pdt.G/2013/PN.Bdg, , in February 18, 2014, p. 3

${ }^{18}$ Supreme Court, Information System of Searching Cases of District Court of Bandung,http://sipp.pnbandung.go.id/detil_perkara, diakses pada tanggal 19 Juli 2019 pukul 20.55 Wib.

${ }^{19}$ Supreme Court, Information System of Searching Cases of District Court of Bandung,http://sipp.pnbandung.go.id/detil_perkara, diakses pada tanggal 19 Juli 2019 pukul 21.00 Wib.
} 


\section{Law Consideration}

Law consideration is the soul and the principle of a verdict. The consideration contains analysis, argumentation, opinion or legal conclusion from the judge who inspects the case. Referring to the analysis, the consideration conducts objective and rational argumentation related to which party that can prove the appeal argumentation as in accordance with the prevailing legal regulations. From the result of argumentation, the judge explains his justification on what is proven and what is not, formulated to be legal conclusion as the principle of case resolution that will be stipulated in the verdict dictum. ${ }^{20}$

The Panel of Judges in the verdict number 274/Pdt.G/2013/PN.Bdg argue that what becomes the principle of case in the appeal of the plaintiff is mainly regarding auction done by the Accused III on the request of the Accused I and as the winner of auction by the Accused II on the disputing object in form of land and building namely a house in Buah Batu Parakan Arum Street Number 9, Batununggal SubDistrict, Bandung Kidul District, Bandung, Ownership Certificate (SHM)Number 4163 Batununggal SubDistrict done in March 21, 2013, as in the Auction Treatise Number 111/2013 is illegal and null and void because the auction limit price of IDR 483.000.000,- (four hundreds eighty three millions rupiah) is improper because it is far from the market value or the minimum price as in Sales Value of Taxable Object of 755.297.000,- (seven hundreds fifty five millions two hundreds ninety seven thousands rupiah);

The judge in handing down a civil verdict is passive. The meaning that judge is passive is the judge hands down a verdict based on the case coverage filed by the plaintiff and related to the evidence provided by the parties. In the verdict number 274/Pdt.G/2013/PN.Bdg, the judge asserts that there are two main principles considered by the judge of District Court of Bandung. The first is regarding the determination of limit value of auction object. In his verdict, the judge argues that all evidences provided by the Accused I does not consist of evidence of appraising result from the appraiser or the appraising team given by bank in casu to the Accused I based on the reliable method so that the determination of value is of 483.000.000,- (four hundreds eighty three millions rupiah) is doubtful for its accuracy whereas the price is under Sales Value of Taxable Oject in 2013 of 755.297.000,-,-( seven thousands fifty five millions two hundreds ninety seven thousands rupiah) and is also under the price of the value of mortgage of IDR 625.000.000,- (six hundreds twenty five millions rupiah).

Besides justification regarding the determination of mortgage object limit value, the second principle considered by the judge is regarding auction announcement. The judge thinks that from the fact above, two provisions regarding auction namely appraising with reliable method and announcement of auction I (first) is not fulfilled by the Accused I whereas by this infulfillment of provision, the Accused II as the auction officer shall annul the auction realization before the auction is started as in line with the provision of Article 27 letter $h$ and $j$ in the Decree of Finance Minister No.93/PMK.06/2010 regarding Guideline of Auction.

Based on two principles considered by the Panel of Judges of District Court of Bandung, the panel of judges argues that the auction done by the Accused I and the Accused II is illegal and not having boundover power. Therefore, the Accused II as the auction winner shall be stated as the buyer who does not have good intention and thus, the action of the accused people is the action against law.

Regarding to the law argumentation delivered by the judge in his law consideration, then the judge hands down a verdict number 274/Pdt.G/2013/PN.Bdg with the verdict injunction as follows:

\footnotetext{
${ }^{20}$ M. Yahya Harahap, Civil Procedure Law Eleventh Printed, Sinar Grafika, Jakarta, 2011, p. 809
} 
In provision:

\section{Adjudicating:}

Rejecting provision indictment from the plaintiffs;

In exception:

Rejecting exception of the Accused I;

In main case :

1. Accepting the suit of the Plaintiffs for a part; $\backslash$

2. Stating that the Accused I, the Accused II, and the Accused III have done action against law;

3. Stating that the Accused II is the auction buyer who has good or bad intention;

4. Stating that mortgage limit value on execution auction by the Accused III in March 21, 2013, Auction Treatise Number 111/2013 null and void or illegal;

5. Stating that the auction by the Accused III in March 21, 2013 in Auction Treatise Number 111/ 2013 is illegal and not having boundover power;

6. Stating that auction treatise Number 111/2013 in March 21, 2013 by the Accused III is illegal and not having boundover power;

7. Commanding the Accused III to annul the Auction Treatise Number 111/2013 in March 21, 2013;

8. Punishing the Accused I, II, and III to pay case cost of IDR 1.516.000,-(one million five hundreds sixteen thousands rupiah)

9. Rejecting the lawsuit of the Plaintiffs for approximately;

The verdict is not the final verdict because it is the verdict in the first level. To the parties that disagree with the verdict have rights to conduct legal attempts towards the verdict. The legal attempt is filing an appeal to Provincial Court of Bandung. In this case, the Accused files an appeal, so that the Accused that previously is the Appealing now becomes the Appealed.

Based on the citation of the verdict record, there is information that towards the case number 274/Pdt.G/2013/PN.Bdg in time period determined by the Law of the Accused I through his attorney power namely Yoga Wisnu Y, based on the Special Power of Attorney dated July 8, 2013, and the Accused II through his attorney power namely Hendi Hendrawan, BA, based on the Special Power of Attorney dated July 17, 2013, in February 27, 2014 has filed an appeal.

After the Panel of Judges of the Provincial Court of Bandung inspects and scrutinizes the case documents and the verdict of the District Court of Bandung Number 274/Pdt/G/2013/PN.Bdg in February 18,2014 , and pays attention on the appeal memory of the Appealing and the appeal memory contra of the Appealed, the Panel of Judges in Appeal Level argues that the auction object limit price is not the absolute requirement to determine the legality of auction and in the provision of Artcile 35 sub-section (2) jo article 36 in the Decree of Finance Minister Number 93/PMK.06/2010 regarding Guideline of Auction has been mentioned that the determination of auction object limit value is the responsibility of seller or the asset owner based on the assessment independently done by the Appraiser based on the competence had or the appraising by the Appraiser/the Appraising Team referring to the reliable method, in which in determining auction object limit value, it is different or it is not only based on Sales Value of Taxable Object, but also it is influenced by other factors.

Based on the consideration, the Panel of Judges of District Court of Bandung hands down their verdict injunction as follows: 


\section{Adjudicating:}

1. Accepting appeal request from the Appealing which is previously the Accused;

2. Annulling the verdict of District Court of Bandung Number 274/Pdt.G/ 2013/PN.Bdg in February 18, 2014 which is requested for appeal, and; ADJUDICATING INDEPENDENTLY:

In provision:

Rejecting provision indictment from the Plaintiff;

In exception:

Rejecting the exception of the Accused I;

In main case:

1. Rejecting law suit for whole;

2. Punishing the Appealed who is previously the Accused to pay case cot in both judicature levels, appeal level's cost is about IDR 150.000,-- (one hundred fifty thousands rupiah)

After the appeal verdict announced by the Panel of Judges of the Provincial Court and informed to the Plaintiff/the Appealed in October 29, 2014, and towards them by the Plaintiff/the Appealed with the help of attorney power, based on the Special Power of Attorney in November 3, 2014 is proposed appeal request in November 4, 2014, as stipulated from the Deed of Appeal Request in November 4, 2014 as stipulated from the Deed of Appeal Request in November 4, 2014 Number 66/Pdt/KS/2014/PN.Bdg. made by th Registrar of District Court of Bandung, the justifications accepted in Secretariat of District Court in November 14, 2014. ${ }^{21}$ After the Panel of Judges inspects the appeal request, the panel of judges hands down a verdict with injunction:

\section{Adjudicating:}

1. Rejecting the appeal request from the Appeal Appellants: 1. H. ARIFIN MARAHAYU, and 2. M. TIO AGUNG SANTIKA MARAHAYU;

2. Punishing the Appeal Appellants/the Plaintiffs to pay case cost in this appeal level of IDR 500.000,00 (five hundreds thousand rupiah);

\section{Analysis of Judge's Consideration}

The problems that will be analyzed by the writers are regarding auction implementation done by State Assets and Auction Service Office based on verdict Number $471 \mathrm{~K} / \mathrm{Pdt} / 2015$ jo 319/PDT/2014/PT.BDG jo 274/Pdt.G/2013/PN.Bdg. In each judicature's verdict, the panel of judges has different rationale regarding justice principle in determining limit value of mortgage auction object done by State Assets and Auction Service Office of Bandung.

In the verdict Number 274/Pdt.G/2013/PN.Bdg, the Panel of Judges states that mortgage object limit value in auction by the Accused III in March 21, 2013 in Auction Treatise Number.111/2013 is null and void or illegal. The justification of the panel of judges in stating that the auction treatise is null and void is caused by the evidences provided by the Accused I do not have evidence of appraising result from the appraiser or the appraising team done by bank in casu of the Accused I based on the reliable method so that the determination of value is of $483.000 .000,-$ (four hundreds eighty three millions rupiah) is doubtful for its accuracy whereas the price is under Sales Value of Taxable Oject in 2013 of 755.297.000,-,-(seven thousands fifty five millions two hundreds ninety seven thousands rupiah) and is also under the price of the value of mortgage of IDR 625.000.000,- (six hundreds twenty five millions rupiah).

\footnotetext{
${ }^{21}$ Supreme Court, Information System of Searching Cases of District Court of Bandung, http://sipp.pnbandung.go.id/detil_perkara, diakses pada tanggal 19 Juli 2019 pukul 21.05 Wib.
} 
Different from the verdict of District Court of Bandung, the Panel of Judges in the Provincial Court of Bandung assumes that the Panel of Judges in Appeal Level arguing that the auction object limit price is not the absolute requirement to determine the legality of auction and in the provision of Artcile 35 sub-section (2) jo article 36 in the Decree of Finance Minister Number 93/PMK.06/2010 regarding Guideline of Auction has been mentioned that the determination of auction object limit value is the responsibility of seller or the asset owner based on the assessment independently done by the Appraiser based on the competence had or the appraising by the Appraiser/the Appraising Team referring to the reliable method, in which in determining auction object limit value, it is different or it is not only based on Sales Value of Taxable Object, but also it is influenced by other factors.

Regarding the sales value under market price, the panel of judges in appeal level state that Sales Value of Taxable Object cannot be taken as a reference of price plateau in auction of mortgage because Sales Value of Taxable Object is the average price obtained from selling-buying transaction occurring properly. While the assessment of auction object is done based on the value per object by paying attention on other factors namely surrounding environment factor and risk factor that will occur because of the auction selling, thus it is normal if the determination of auction object limit price will lead to different value and is under Sales Value of Taxable Object, in which it does not mean that the seller in determining the auction object limit value is not based on the reliable method. Then, the appeal verdict number 319/PDT/2014/PT.BDG is strengthened by appeal verdict number $471 \mathrm{~K} / \mathrm{Pdt} / 2015$.

If reviewing the appeal verdict Number 471 K/Pdt/2015 jo 319/PDT/2014/PT.BDG jo 274/Pdt.G/2013/PN.Bdg, there is different viewpoints of the judges in seering the determination of mortgage limit value. From the judge's consideration, the judges use textual ${ }^{22}$ and contextual approaches 23. Mainly, both approach patterns are unfinished disputes between the believers of law positivism and progressive law.

By referring to the determination of the mortgage limit value, if reviewed textually or contextually, it indeed still has defect that can be made as a law discourse room. As known commonly in Article 35 sub-section 2 jo article 36 in the Decree of Finance Minister Number 93/PMK.06/2010 which is then transformed to Article 1 number 28 27/PMK.06/2016 regarding Guideline of Auction stating that Limit Value is the minimum price of asset that will be aucted and determined by the auction appellant.

Regarding the mortgage limit determination done by the mortgage parate executie appellants, it is procedural according to the Decree of Finance Minister Number 93/PMK.06/2010 regarding Guideline of Auction. Indeed, if it refers to the provision of Article 35 sub-section 2 jo article 36 of the Decree of Finance Minister Number 93/PMK.06/2010 regarding Guideline of Auction has mentioned that the determination of auction object limit value is the responsibility of the seller/the owner of asset based on the independent assessment by the Appraiser.

Based on the provision of Article 35 sub-section 2 jo Article 36 in the Decree of Finance Minister, it gives authorities to the auction appellants imperatively to conduct assessment towards mortgage object. The mechanism of mortgage object limit value determination by the auction appellants is imperative because the norm is the authority delegated by the government through decree of Finance Minister.

\footnotetext{
${ }^{22}$ Textual approach is a text-based approach. Text according to Indonesian Dictionary is the script in form of original words from the author. Textual word is the adjective of text word or based on text. From here, the term textual approach is related to understanding on meaning and intention in norms of legal regulation.

${ }^{23}$ Terminology of contextual itself has several definitions according to Noeng Muhadjir, at least there are three different definitions, namely 1) several attempts to understand meaning for the sake of anticipating current problems that commonly appear; 2) the meaning that sees past, present, and future relevance where something will be seen from past history point, present functional meaning, and future relevant meaning prediction; and 3) showing the relation between central and peripheral; central means as text of regulation norms and periphery means its implementation.
} 
Based on the executor regulation, it has given explanation who has authority to determine the mortgage auction object, but the Decree of Finance Minister Number 93/PMK.06/2010 regarding Guideline of Auction that has been updated to be the Decree of Finance Minister Number 27/PMK.06/2016 does not regulate how to implement limit value as in line with market price ${ }^{24}$ and when it is able to use liquidity value ${ }^{25}$ for mortgage object auction in order to achieve justice principles in the auction implementation.

Different opinions between panel of judges in District Court and Provincial Court of Bandung regarding the determination of mortgage object auction limit value can be viewed by using Legal Certainty Theory according to Van Apeldoorn. Van Apeldoorn states that a verdict handed down by judge shall be able to determine case resolution by providing real and concrete consideration, and having measurable consideration fundamental, so that the parties in case can know what provisions that will be used in solving it.

By referring to Legal Certainty Theory according to Van Apeldoorn, the judge's verdict reflecting to legal certainty principle is also in the judge's verdict of District Court of Bandung. In the consideration, the Panel of Judges states that the auction treatise is illegal because the creditor is not able to be responsible regarding the method used by the appraiser in appraising the mortgage object limit value. The panel of judges assumes that the determination of mortgage object limit value shall use measurable method.

The viewpoint of the Panel of Judges in the District Court is annulled by the Provincial Court of Bandung which is strengthened by the appeal verdict of Supreme Court of the Republic of Indonesia. The Panel of Judges of Provincial Court argues that the determination of auction object limit value is not the absolute requirement to determine the legality of auction and assumes that the auction object price under the market price is normal because mortgage auction has risks that will occur because of the auction selling.

The legal opinion of Panel of Judges in this Provincial Court of Bandung does not meet the legal certainty principle. The opinion stating that the determination of limit value is not the absolute requirement to determine the legal of auction is a wrong opinion because the determination of limit value is formal regulation in mortgage auction implementation. If a legal action violates formal regulation, the legal action can cause to null and void because it is an action against $\operatorname{law}^{26}$.

Besides, the opinion of the Panel of Judges of Provincial Court stating proper that the determination of auction object limit price will lead to different value and is under Sales Value of Taxable Object because the risk factor that will occur because of the auction selling. The opinion of the Panel of Judges asserting that a limit price assessment that can be under the market price is the legal finding that cannot be measured so that it causes legal incertainty because there is no regulation of auction

\footnotetext{
${ }^{24}$ Market price is defined as the estimation of money in assessment date, that can be obtained from selling-buying transaction or the result of property exchange, between the buyer who intends to buy and the seller who intends to sell, in a free-bound transaction, which its marketing is done properly, in which both parties respectively acts on understanding base thet have, carefulness, and no force (3.1.SPI 1, SPI 2007)

${ }^{25}$ Liquidity Value is amount of money that is likely received from the selling of an asset in a relatively short term to fulfill marketing term in the definition of market value. (3.7. SPI 2, SPI 2007)

${ }^{26}$ Munir Fuadi, 2017, Action Against Law: Contemporary Approach, the Fifth Printed, PT.Citra Aditya Bakti, Bandung, p. 11. Action against law according to Munir Fuadi meets elements of against the law if it includes: a. action violating prevailing laws; b. that violates other people's rights guaranteed by laws;; c. Action conflicting with the law obligation of the doer; d. Action conflicting with morality (goede zeden); Action conflicting with good attitude in the community to pay attention on other people's interests (indruist tegen de zorgvuldigheid, welke in het maatschappelijk verkeer betaamt ten aanzien van anders persoon of goed).
} 
implementation that sets the percentage of auction implementation risk and when to use the liquidity assessment in the determination of limit value in auction.

If the Decree of Finance Minister regulating about technical guideline of mortgage object auction does not set when to use the limit value basd on the market price and liquidity value of auction object, it will lead to legal incertainty that causes abuse of power from the auction appellants.

\section{Conclusion}

1. The judge's consideration regarding the implementation of mortgage parate executie under the plateau price in the effort of solving bad load determined by judge's approach used in analyzing the problems. The judge's verdict that uses approach textually tends to prioritize legal certainty. This kind of judge does not dig the values contained behind the problems faced to them. Different from judge who uses approach contextually that prioritizes justice principle in seeing the problems faced by them. This judge will search for solution through legal findings if the cases that will be handed down has multi-interpreted legal regulation or between regulation on laws and the executing regulation are not in line. The difference of judges that makes the verdict Number $471 \mathrm{~K} / \mathrm{Pdt} / 2015 \mathrm{jo}$ 319/PDT/2014/PT.BDG jo 274/Pdt.G/2013/PN.Bdg, has difference from respective judicature level.

2. The attempt that can be done to implement just mortgage parate executie for the community is by doing material testing towards the Decree of Finance Minister Number 27/PMK.06/2016 regarding Guideline of Auction in Article 1 number 28. It is caused by the content of the article can cause abuse of function in the implementation of mortgage parate executie. The pursuit that can be requested in the material testing of the Decree of Finance Minister Number 27/PMK.06/2016 to add authority of State Assets and Auction Service Office as the authorized institution in doing correction towards the determination of mortgage object limit value so that the check and balance in determining mortgage object limit value is there.

\section{References}

Books

Amiruddin dan Zainal Asikin, 2003, Pengantar Metode Penelitian Hukum, Rajawali Pers, Jakarta.

Anton Suyatno, 2018, Kepastian Hukum dalam Penyelesaian Kredit Macet, Prenadamedia, Depok.

Boedi Harsono, 2005, Hukum Agraria Indonesia, Ed.rev cet 10, Djambatan, Jakarta.

Djoni S. Gazali dan Rachmadi Usman, 2010, Hukum Perbankan, Sinar Grafika, Jakarta.

Dominikus Rato, 2010, Filsafat Hukum, Laskbang Pressindo, Yogyakarta. 
Hermansyah, 2006, Hukum Perbankan Nasional Indonesia, Edisi Revisi, Kencana, Jakarta.

Herowati Poesoko, 2013, Parate Executie Obyek Hak Tanggungan, Aswaja Pressindo, Yogyakarta.

I Made Pasek Diantha, 2017, Metodologi Penelitian Hukum Normatif, Prenada.

J. Satrio, 1998, Hukum Jaminan, Hak Jaminan Kebendaan, Hak tanggungan, Citra Aditya Bakti, Bandung. , 1999, Cessie, Subrogatie, Novatie, Kompensatie \& Pencampuran Hutang, Alumni, Bandung.

Jan Micheil Otto, 2003, Kepastian Hukum di Negara Berkembang, terjemahan.

Komarudin, 1974, Metode Tulisan Skripsi dan Thesis, Citra Grafika, Bandung.

Lilik Mulyadi, 1996, Tuntutan Provisional dalam Hukum Acara Perdata, Djambatan, Jakarta.

Mardalis, 2010, Metode Pendekatan Suatu Pendekatan Proposal, Bumi Aksara, Jakarta.

Miriam Budiardjo, 1998, Dasar-Dasar Ilmu Politik, Gramedia Pustaka Utama, Jakarta.

Muhammad Abdul Kadir dan Murniarti Rilda, 2000, Lembaga Keuangan dan Pembiayaan, PT Citra Aditya Bakti, Bandung.

Muhamad Djumhana, 2001, Hukum Perbankan di Indonesia, Citra Aditya Bakti, Bandung.

Munir Fuady, 2013, Teori-Teori Besar Dalam Hukum, Kencana, Jakarta. , 2013, Hukum Jaminan Utang, Erlangga, Surabaya.

Peter Mahmud Marzuki, 2010, Penelitian Hukum, Kencana Pranada Media Group, Jakarta.

Philipus M. Hadjon, Tentang Wewenang, Makalah, Universitas Airlangga, Surabaya.

Rachmadi Usman, 2008, Hukum Jaminan, Ed 1. Cet 1, Sinar Grafika, Jakarta.

Retnowulan Sutantio dan Oerip Kartawinata, 1997, Hukum Acara Perdata dalam Teori dan Praktik, Mandar Maju, Bandung.

Riky Rustam, 2017, Hukum Jaminan, UII Press, Yogyakarta.

Ridwan HR, 2014, Hukum Administrasi Negara, PT Radja Grafindo Persada, Jakarta.

Rusadi Kantaprawira, 1998, Hukum dan Kekuasaan, Makalah, Universitas Islam Indonesia, Yogyakarta.

R.Soeroso, 2011, Pengantar Ilmu Hukum, cetakan 12, Sinar Grafika, Jakarta.

Salim HS, 2004, Perkembangan Hukum Jaminan di Indonesia, PT Raja Grafindo Persada, Jakarta.

Soejono Soekanto, 1974, Beberapa Permasalahan Hukum dalam Kerangka Pembangunan Indonesia, UI Press, Jakarta. 
Sudikno Mertokusumo, 2006, Hukum Acara Prdata Indonesia, Cet.I, Liberty, Yogyakarta.

Suratman dan Philips Dillah, 2012, Metode Penelitian Hukum, CV Alfabeta, Bandung.

Sutan Remy Sjahdeini, 1999, Hak Tanggungan (Suatu Kajian Mengenai Undang-Undang Hak Tanggungan), Alumni, Bandung.

Sutarno, 2003, Aspek-Aspek Hukum Perkereditan pada Bank, Alfabeta, Bandung.

Urip Santoso, 2012, Hukum Agraria Kajian Komprehensif, kencana, Jakarta.

Zainuddin Ali, 2009, Metodelogi Penelitian Hukum, Sinar Grafika, Jakarta,

Legislation

The 1945 Constitution of the Republic of Indonesia

Civil Code

Law No. 4 of 1996 concerning Mortgage Rights

Minister of Finance Regulation No. 93/PMK.06/2010 concerning Guidelines of Auction Implementation

Circular Letter of the Supreme Court No. 4 of 2014 concerning the Imposition of the Results of the Supreme Court Room Plenary Meeting 2013 as a Guideline for the Implementation of Duties for the Court

\section{Court Decision}

Bandung District Court Decision No. 274/Pdt.G/2013/PN.Bdg

Bandung High Court Decision No. 319/PDT/2014/PT BDG

Supreme Court Decision No. 471K/PDT2015

\section{Copyrights}

Copyright for this article is retained by the author(s), with first publication rights granted to the journal.

This is an open-access article distributed under the terms and conditions of the Creative Commons Attribution license (http://creativecommons.org/licenses/by/4.0/). 